OPEN ACCESS

Edited by:

Bin Tang,

Hangzhou Normal University, China

Reviewed by:

Honggang Tian,

Northwest A\&F University, China Xianchun $\mathrm{Li}$,

University of Arizona, United States

${ }^{*}$ Correspondence: Zhaojun Han zjhan@njau.edu.cn

Specialty section: This article was submitted to Invertebrate Physiology, a section of the journal Frontiers in Physiology

Received: 26 January 2018 Accepted: 08 May 2018 Published: 28 May 2018

Citation:

Peng Y, Wang K, Fu W, Sheng C and Han Z (2018) Biochemical Comparison of dsRNA Degrading Nucleases in Four Different Insects.

Front. Physiol. 9:624. doi: 10.3389/fphys.2018.00624

\section{Biochemical Comparison of dsRNA Degrading Nucleases in Four Different Insects}

\author{
Yingchuan Peng, Kangxu Wang, Wenxi Fu, Chengwang Sheng and Zhaojun Han*
}

The Agricultural Ministry Key Laboratory of Monitoring and Management of Plant Diseases and Insects, Department of Entomology, College of Plant Protection, Nanjing Agricultural University, Nanjing, China

Double stranded RNAs (dsRNA) degrading nuclease is responsible for the rapid degradation of dsRNA molecules, and thus accounts for variations in RNA interference (RNAi) efficacy among insect species. Here, the biochemical properties and tissuespecific activities of dsRNA degrading nucleases in four insects (Spodoptera litura, Locusta migratoria, Periplaneta americana, and Zophobas atratus) from different orders were characterized using a modified assay method. The results revealed that all insect dsRNA degrading nucleases tested showed high activity in alkaline environments at optimal $\mathrm{Mg}^{2+}$ concentrations and elevated temperatures. We also found that enzymes from different insects varied in terms of their optimal reaction conditions and kinetic parameters. Whole body enzyme activity differed dramatically between insect species, although enzymes with higher substrate affinities (lower $K_{m}$ ) were usually balanced by a smaller $V_{\max }$ to maintain a proper level of degradative capacity. Furthermore, enzyme activities varied significantly between the four tested tissues (whole body, gut, hemolymph, and carcass) of the insect species. All the insects tested showed several hundred-fold higher dsRNA degrading activity in their gut than in other tissues. Reaction environment analysis demonstrated that physiological conditions in the prepared gut fluid and serum of different insects were not necessarily optimal for dsRNA degrading nuclease activity. Our data describe the biochemical characteristics and tissue distributions of dsRNA degrading activities in various insects, not only explaining why oral delivery of dsRNA often produces lower RNAi effects than injection of dsRNA, but also suggesting that dsRNA-degrading activities are regulated by physiological conditions. These results allow for a better understanding of the properties of dsRNA degrading nucleases, and will aid in the development of successful RNAi strategies in insects.

\section{Keywords: RNA interference, nuclease, dsRNA degrading enzyme, dsRNase, fluorescence}

\section{INTRODUCTION}

Since the first demonstration of long, double stranded RNAs (dsRNA) mediating RNA interference (RNAi) in Caenorhabditis elegans (Fire et al., 1998), RNAi technology has been widely used in scientific research, clinical applications, and agricultural pest control in the past decades (Baum et al., 2007; Price and Gatehouse, 2008; Bellés, 2010; Burand and Hunter, 2013; 
Zhang et al., 2017). RNA interference is achieved by administration of dsRNA to the target site, where it is then processed into small interfering RNA (siRNA) by Dicer enzyme and coupled with Argonaute protein to form an RNA-induced silencing complex (RISC), which combines with complementary mRNA to induce target RNA degradation (Meister and Tuschl, 2004).

The elements involved in RNAi are indispensable for successful gene silencing (Mello and Conte, 2004; Tijsterman et al., 2004). The core RNAi machineries contributing to robust RNAi responses are widely distributed among various insect species (Tomoyasu et al., 2008; Wynant et al., 2012; Liu et al., 2013; Swevers et al., 2013; Xu et al., 2013; Ghosh et al., 2014). Currently, it is difficult to successfully silence genes with dsRNA in some insects, such as lepidopterans, which are refractory to RNAi (Terenius et al., 2011). Systemic RNAi efficiency variation among different insects has been a barrier to the application of RNAi as an effective tool for functional genomic research, and also to the biological control of pests by dsRNA-expressing transgenic plants and gene-specific dsRNA insecticides (Terenius et al., 2011; Zhang et al., 2013; Kola et al., 2015; Joga et al., 2016). Systemic RNAi requires the spread of dsRNA throughout the whole body, which relies on stable transition and uptake of dsRNA (Huvenne and Smagghe, 2010). Critically, dsRNA molecules must avoid degradation by nucleases if they are to maintain long-term stability before reaching target sites and inducing a sustainable RNAi response. It is necessary to better understand the factors underlying the diversity of dsRNA degrading activities in the hemolymph and gut lumen of different insect species.

Our previous studies found that different degrees of dsRNA degradation in the gut and hemolymph were consistent with variations in RNAi efficacy among insects (Wang et al., 2016). Previous reports have demonstrated that degradation of dsRNA was a major factor limiting RNAi efficacy in lepidopteran insects (Shukla et al., 2016). In the Colorado potato beetle, Leptinotarsa decemlineata, which is sensitive to RNAi response by oral delivery of dsRNA, depletion of nuclease activity by interfering dsRNase (a member of the DNA/RNA non-specific endonuclease family) in the gut increased dsRNA stability and resulted in an improved RNAi response (Spit et al., 2017). In the migratory locust Locusta migratoria, a dsRNase was found to be responsible for the poor RNAi response associated with oral delivery of dsRNA. Knockdown of the gene encoding this gut-specific dsRNase enhanced the RNAi response (Song et al., 2017). Additional evidence has shown that the gut fluid, hemolymph, and saliva of different insects digests dsRNA, which may negatively impact RNAi efficacy (Furusawa et al., 1993; Allen and Walker, 2012; Liu et al., 2012; Garbutt et al., 2013; Christiaens and Smagghe, 2014; Ren et al., 2014; Wynant et al., 2014; Lomate and Bonning, 2016; Almeida Garcia et al., 2017; Luo et al., 2017; Singh et al., 2017).

It has been shown that dsRNA may be absorbed and spread throughout the whole insect body (Huvenne and Smagghe, 2010; Ivashuta et al., 2015). Multiple nucleases may therefore be involved in dsRNA degradation. Besides siRNA-degrading enzymes like Eri-1, which function as secondary degrading enzymes of dsRNA, two kinds of dsRNA degrading enzymes have been identified in insects, namely Dicers and dsRNases. Dicers and dsRNases are always encoded by several genes in an insect, and different insect species usually differ in terms of their expression profiles (Tomoyasu et al., 2008; Liu et al., 2012; Wynant et al., 2014; Luo et al., 2017; Song et al., 2017; Spit et al., 2017). It is difficult to compare dsRNA degrading nucleases from different species because their identities remain largely unknown. The most well-studied dsRNases are members of a large family of DNA/RNA non-specific endonucleases, which were usually found constitutively over-expressed in the insect gut, and are thought to target and degrade foreign dsRNAs (Liu et al., 2012; Wynant et al., 2014; Luo et al., 2017; Song et al., 2017; Spit et al., 2017). As mentioned above, the strong cleavage activity of widely distributed gut-specific dsRNases against dsRNA molecules has been confirmed in different insects. These enzymes are a type of secretory nuclease expressed in a variety of tissues (Liu et al., 2012; Garbutt et al., 2013; Almeida Garcia et al., 2017; Luo et al., 2017). Some are overexpressed in the gut (Garbutt et al., 2013; Wynant et al., 2014; Almeida Garcia et al., 2017; Luo et al., 2017; Song et al., 2017; Spit et al., 2017). They play key roles in lowering RNAi efficiency by degrading dsRNA into non-functional fragments. Dicer is another well-known dsRNA degrading enzyme which functions intracellularly as part of the core RNAi machinery, cutting dsRNA into siRNA within various cells to regulate gene expression during insect development (Sinha et al., 2015). These enzymes also degrade endogenous or invading dsRNAs (Marques et al., 2013). Though positive for RNAi, Dicers also degrade dsRNA into siRNA directly. The siRNA may then be degraded by other nucleases. Thus, siRNA-degrading nucleases could promote dsRNA degradation by functioning as secondary degrading enzymes (Kennedy et al., 2004; Kupsco et al., 2006; Tomoyasu et al., 2008; Han et al., 2011; Swevers et al., 2013; Xu et al., 2013; Christiaens et al., 2014; Sinha et al., 2015). Recently, intracellular siRNA-degrading Eri-1-like nucleases were found to inhibit RNAi. Interference of their expression in C. elegans enhanced RNAi efficacy (Kennedy et al., 2004). However, their negative function against RNAi has not been confirmed in insects. Further studies might reveal additional nucleases degrading dsRNA in various insects. Therefore, when investigating factors which affect dsRNA persistence in insects, all enzymes present in a species, known and unknown, should be taken into consideration. For this reason, in the present study we considered all the enzymes involved by using homogenate supernatants recovered, from either whole insect bodies or from selected tissues, as enzyme sources for comparison, and hope the weighted average obtained with integrated enzymes could present well the dsRNA degrading activities of different insect species and tissues.

Considering that insects usually differ in terms of their physiological states, and that enzyme activity always varies with catalyzing reaction conditions, we hypothesized that not only regulation of enzyme expression, but also the reaction environments of the gut and hemolymph influence dsRNA degradation rates among different insects. Thus, characterizing 
the physiological conditions of the gut and hemolymph in different insects and pursuing the mechanisms whereby dsRNAdegrading activity is regulated could help us establish a more comprehensive understanding of the major factors that affect dsRNA persistence. This will be helpful in establishing efficient strategies to improve dsRNA stability.

Traditionally, dsRNA degrading activities have been assayed by analyzing substrate residues using gel electrophoresis and spectrometer absorbance at $\mathrm{OD}_{260}$ (Arimatsu et al., 2007a; Liu et al., 2012). These methods do not allow for precise, quantitative tests. Recently, a more accurate method was developed which analyzes residual dsRNA molecules using quantitative PCR (Garbutt et al., 2013; Wang et al., 2016). This method has the disadvantage of being impractical when large quantities of samples must be analyzed. However, the continuous fluorescence intensity measurement method developed for Dicer cleavage assays is applicable for such analyses (Podolska et al., 2014). Here, we modified the method by selecting a suitable fluorophore and quencher pair and developed a fluorescence method for quantification of dsRNA degrading activity (Figure 1).

\section{MATERIALS AND METHODS}

\section{Insects}

Four species of insects representing different orders were compared in this study. For comparative analysis, the insects used in the following experiments were at the same developmental stage as those used in the previous RNAi experiments: middle $6^{\text {th }}$ instar tobacco caterpillar larvae (Spodoptera litura, Lepidoptera), 2-day-old adult migratory locusts (Locusta migratoria, Orthoptera), 3-day-old adult American cockroaches (Periplaneta americana, Blattaria), and middle $5^{\text {th }}$ instar tenebrionid beetle larvae (Zophobas atratus,

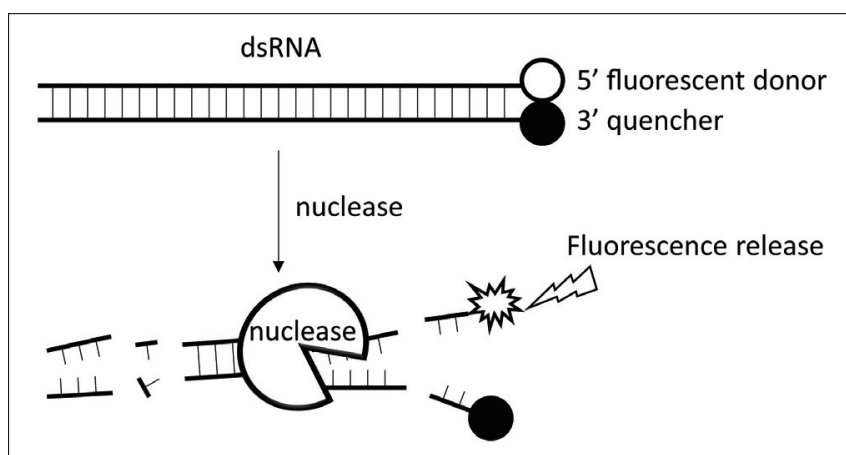

FIGURE 1 | The working principle of the fluorescence method. A 24-bp synthesized dsRNA with a fluorophore group attached to the $3^{\prime}$ end of its sense strand and a quencher group to the $5^{\prime}$ end of its antisense strand is used as the substrate for analysis of dsRNA nucleases. No fluorescence is emitted when the substrate remain intact as the quencher group inhibits the fluorophore group. When dsRNA nuclease is added to the reaction tube, the dsRNA substrate will be gradually degraded, leading to separation of the fluorophore group from the quencher group, and thus the emission of the corresponding fluorescence light. The more the dsRNA degraded, the stronger the fluorescence signal.
Coleoptera). These insects were selected because they were all in their gluttonous feeding phase and had similar body weights. Insect rearing conditions are described in our previous study, and their sensitivities to RNAi with both injection and ingestion of dsRNA have been reported (Wang et al., 2016).

\section{Preparation of dsRNA Substrate}

Two substrate types were prepared for dsRNA degrading activity analysis: naked and fluorophore-labeled. For the gel electrophoresis assay, $414 \mathrm{bp}$ of naked dsRNA without fluorophore modification was synthesized using enhanced green fluorescence protein gene (EGFP, GenBank accession: DQ389577.1) as template, and using in vitro transcription and the T7 RiboMAX Express RNAi System (Promega, Madison, WI, United States). A pair of primers (Forward: 5'-AAGTTCAGCGTGTCCGGC-3', Reverse: 5' CACCTTGATGCCGTTCTTC-3') containing $5^{\prime}$ T7 promoter sites (5'-TAATACGACTCACTATAGGG-3') targeting EGFP was used to generate the DNA template. Purified dsRNA was dissolved in nuclease-free water and stored at $-80^{\circ} \mathrm{C}$ for further use. The quality of all the dsRNA products was checked by gel electrophoresis on $1.2 \%$ agarose, and nucleotide concentrations were measured using a NanoDrop ND-1000 spectrophotometer (Thermo Fisher Scientific, Waltham, MA, United States) and adjusted before use. For the fluorescence assay, the fluorescent conjugated dsRNA substrate, which was a 24 bp dsRNA targeting EGFP (Sense strand: 5' -ACUUAGCUUAGCACAAACAACCCG-3', Antisense strand: 5'-CGGGUUGUUUGUGCUAAGCUAAGU-3'), was synthesized by GenePharma Company (Shanghai, China). The $5^{\prime}$ end of the sense strand was labeled with fluorophore and $3^{\prime}$ end of the antisense strand was labeled with quencher.

\section{Insect Dissection}

To collect the hemolymph, gut fluid, gut, and carcass (without gut and hemolymph), the insects were anesthetized on ice prior to dissection. The hemolymph and gut fluid were collected following the procedure described in our previous study (Wang et al., 2016). The guts were dissected and transferred to $1.5 \mathrm{~mL}$ micro centrifuge tubes, and then cut into pieces. The gut fluid was obtained by centrifugation at $16,000 \times g$ for $10 \mathrm{~min}$ at $4^{\circ} \mathrm{C}$ to remove tissues. Hemolymph was collected with pipettes and transferred to $1.5 \mathrm{~mL}$ micro centrifuge tubes. The serum was prepared from the hemolymph by centrifugation at $16,000 \times g$ for $10 \mathrm{~min}$ at $4^{\circ} \mathrm{C}$ to remove cells. The remainder of the insect body was collected as the carcass after removing the hemolymph and the gut. After dissection, collected tissues were flash frozen in liquid nitrogen immediately prior to homogenization in 0.1 M Glycine-KOH buffer. Homogenization was performed using $1 \mathrm{~g}$ extract in $8 \mathrm{~mL} 0.1 \mathrm{M}$ Glycine$\mathrm{KOH}$ buffer with specific $\mathrm{pH}$ values adjusted according to the requirements of individual experiments. All of the whole-body sample sets contained at least three insect individuals, and those representing guts and hemolymph came from at least five insect individuals. All experiments were performed with three biological replications and all tests with three technical replications. 


\section{Measurement of dsRNA Degrading Activity by Fluorescence Method}

Optimal reaction conditions for the enzymes from different insects were determined before further experimentation was carried out. Glycine- $\mathrm{KOH}$ buffer (with $\mathrm{pH}$ ranging from 6.5 to 11.0 ) containing $0.1 \mathrm{M}$ glycine, $0.1 \mathrm{M} \mathrm{NaCl}, 1 \mathrm{mM} \mathrm{MgCl}_{2}$, $1 \mathrm{mM}$ phenylthiourea (PTU), $1 \mathrm{mM}$ dithiothreitol (DTT), $1 \mathrm{mM}$ phenylmethanesulfonyl fluoride (PMSF) and 10\% glycerol was used as homogenization and reaction buffer when determining optimal $\mathrm{pH}$. Whole insect bodies were homogenized on ice using a glass homogenizer, and the crude enzyme lysate was cleared by centrifugation at $16,000 \times g$ for $10 \mathrm{~min}$ at $4^{\circ} \mathrm{C}$. The supernatant was transferred to a new microcentrifuge tube and centrifuged again at $16,000 \times g$ for $20 \mathrm{~min}$ at $4^{\circ} \mathrm{C}$. The final supernatant was then collected as crude enzyme solution. The dsRNA degradation assays were conducted in black, flat-bottom, polystyrene 384-well microplates (Corning, NY, United States). Reaction mixtures containing $19 \mu \mathrm{L}$ crude enzyme solution and $1 \mu \mathrm{L}(10 \mu \mathrm{M})$ fluorescent conjugated dsRNA substrate were incubated at $37^{\circ} \mathrm{C}$. Fluorescence intensity was continuously measured with a Softmax M5 Pro Multi wavelength fluorescence reader (Molecular Devices, Sunnyvale, CA, United States), with readings taken at $30 \mathrm{~s}$ intervals for $60 \mathrm{~min}$. To determine the optimal magnesium concentration, $19 \mu \mathrm{L}$ of crude enzyme solutions containing different concentrations of magnesium (0$64 \mathrm{mM})$ at the predetermined optimal $\mathrm{pH}$ were incubated with $1 \mu \mathrm{L}(10 \mu \mathrm{M})$ fluorescent conjugated dsRNA substrate. To determine the optimal temperature, $19 \mu \mathrm{L}$ crude enzyme solutions containing the optimal magnesium concentration at the optimal $\mathrm{pH}$ were incubated with $1 \mu \mathrm{L}(10 \mu \mathrm{M})$ fluorescent conjugated dsRNA substrate at a range of temperatures. The rate of dsRNA degradation indicated by changes in Rate of Fluorescence Units (RFU $\cdot \mathrm{s}^{-1}$ or RFU $\cdot \mathrm{mg}^{-1}$ protein $\cdot \mathrm{s}^{-1}$ ) was calculated based on the initial linear velocity by plotting fluorescence intensity (RFU) against time.

Kinetic parameters of the enzymes from different insects were determined using their individualized optimal reaction conditions. Different concentrations of the fluorescent conjugated dsRNA substrate were incubated with the crude enzyme, prepared as described above, in a total volume of $20 \mu \mathrm{L}$. Steady-state kinetic parameters were estimated by measuring the rate of reaction over the linear range with respect to time, with substrate concentrations ranging from 0 to $16 \mu \mathrm{M}$. Calculations were performed by fitting the data to the Michaelis-Menten equation using GraphPad Prism 6.03 (GraphPad Software Inc., La Jolla, CA, United States).

\section{Visualization of dsRNA Degrading Activity by Gel Electrophoresis}

Enzyme solutions were prepared by dilution of the gut fluid and serum collected from the tobacco caterpillar with nuclease free water. Both gut fluid and serum were diluted 20 -fold. Then, $19 \mu \mathrm{L}$ of the dilutions were incubated with $1 \mu \mathrm{L}(1 \mu \mathrm{g})$ of the $414 \mathrm{bp}$ naked dsRNA at $37^{\circ} \mathrm{C}$, and samples were collected at different time points $(2,10,30,60$, and $120 \mathrm{~min}$, respectively). After collection, $1 \mu \mathrm{L}$ of proteinase K (Qiagen, Hilden, Germany) was immediately added to the samples, which were incubated at $55^{\circ} \mathrm{C}$ for 15 min to stop the RNA-degrading reaction and eliminate proteins. The integrity of residual dsRNA was then evaluated by electrophoresis on a $1.5 \%$ agarose gel. The bands were visualized with ethidium bromide (EtBr) under ultraviolet light.

\section{Measurement of dsRNA Degrading Activity by Quantitative Real-Time PCR (qPCR) Analysis}

Naked 414 bp dsRNA was used as substrate and incubated with enzyme solutions at $37^{\circ} \mathrm{C}$ for $5 \mathrm{~min}$ in a total volume of $20 \mu \mathrm{L}$. Then, $350 \mu \mathrm{L}$ buffer-RLT from the RNeasy Micro Kit (Qiagen, Hilden, Germany) was added to stop the reaction, and the residual dsRNA was extracted by using this kit. Quantitative measurement of residual dsRNA content was conducted as described previously (Garbutt et al., 2013; Wang et al., 2016). The dsRNA samples were denatured at $65^{\circ} \mathrm{C}$ for 5 min prior to cDNA preparation by reverse transcription using a PrimeScript ${ }^{\mathrm{TM}}$ 1st Strand cDNA Synthesis Kit (TaKaRa, Dalian, China). The residual dsRNA content was quantified using qPCR performed with SYBR $^{\circledR}$ Premix Ex Taq ${ }^{\mathrm{TM}}$ reagent (TaKaRa) and Applied Biosystems 7500 System (Life Technologies, Carlsbad, CA, United States). The qPCR reaction mix containing $10 \mu \mathrm{L}$ SYBR mix, $0.4 \mu \mathrm{L}$ each of forward and reverse gene-specific primer (Forward: 5'-GACGACGGCAACTACAAGAC-3', Reverse: $5^{\prime}$-GTCCTCCTTGAAGTCGATGC-3'), $0.4 \mu$ L ROX dye reagent of the kit, and $1 \mu \mathrm{L}$ of cDNA template. Nuclease-free water $(7.8 \mu \mathrm{L})$ was added to a final volume of $20 \mu \mathrm{L}$. The qPCR program was as follows: $95^{\circ} \mathrm{C}$ for $30 \mathrm{~s}, 40$ cycles at $95^{\circ} \mathrm{C}$ for $5 \mathrm{~s}$, and $60^{\circ} \mathrm{C}$ for $34 \mathrm{~s}$. Residual dsRNA content was quantified using the formula derived from the calibration experiments with serially diluted dsRNA in the inactivated gut fluid solution $\left(y=-3.340 x+34.58, r^{2}=0.9901\right)$. Rate of dsRNA degradation was calculated using the following formula: $(1,000,000$-residual dsRNA)/300, with units expressed as $\mathrm{pg} \cdot \mathrm{s}^{-1}$.

\section{Measurement of Tissue $\mathrm{pH}$ and Magnesium Ion Concentrations}

Fresh serum and gut fluid were prepared from the different insect species. The $\mathrm{pH}$ values of serum and gut fluids were measured using an InLab ${ }^{\circledR}$ Ultra-Micro pH electrode (Mettler-Toledo, Greifensee, Switzerland) (Harrison, 2001). For magnesium concentration measurement, the serum and gut fluids were first digested with $\mathrm{HNO}_{3}$ for 40 min with a microwave digestion system (Milestone Ethos T, Sorisole, BG, Italy), after which digested solutions were transferred to volumetric flasks and diluted with $1 \% \mathrm{HNO}_{3}$ to a final volume of $50 \mathrm{~mL}$. The magnesium ion concentration in the solutions were measured using inductively coupled plasma-mass spectrometry (ICP-MS) with axial and radial viewing plasma configuration Model Optima 8000 (PerkinElmer, Waltham, MA, United States) (Zhou et al., 2007).

\section{Protein Quantification}

Protein concentrations in crude enzyme solutions were determined by Bradford assay using bovine serum albumin 
(BSA) as standard. The reaction mixtures, containing $10 \mu \mathrm{L}$ protein solutions and $270 \mu \mathrm{L}$ Coomassie brilliant blue, were incubated at $25^{\circ} \mathrm{C}$ for $5 \mathrm{~min}$ and the absorbance subsequently measured at $595 \mathrm{~nm}$ with a Softmax M5 Pro Multi wavelength fluorescence reader (Molecular Devices, Sunnyvale, CA, United States).

\section{Statistical Analysis}

Correlation analyses of differences between dsRNA-degrading activity determined by fluorescence and qPCR methods were performed in GraphPad Prism 6.03 (GraphPad Software Inc., La Jolla, CA, United States) using Pearson's correlation coefficient. The statistical significance of differences in dsRNA degrading activity and in physiological conditions of different insect species were determined by one-way analysis of variance (ANOVA) followed by Tukey's test using SPSS Statistics 20.0 software (IBM, NY, United States).

\section{RESULTS}

\section{Development of a Method for Enzymatic Analysis of dsRNA Degrading Nucleases}

The continuous fluorescence intensity measurement method developed for the Dicer cleavage assay was first reported by Podolska et al. (2014). The principle is illustrated in Figure 1.

\section{Fluorophore/Quencher Selection}

Suitable fluorophore and quencher couples were selected for quantification of dsRNA degradation rate. Three different combinations of fluorophore and quencher types were considered: 5-FAM fluorescent donor and 3-BHQ1 quencherlabeled strands (5-FAM/3-BHQ1), 5-Cy3 fluorescent donor and 3-BHQ2 quencher-labeled strands (5-Cy3/3-BHQ2), and 5-Cy5 fluorescent donor and 3-BHQ2 quencher-labeled strands (5Cy5/3-BHQ2). When tobacco caterpillar gut fluid was used as the nuclease source and incubated with the 24 bp dsEGFP substrates labeled with these fluorescent and quencher combinations at a final concentration of $0.5 \mu \mathrm{M}$ dsRNA, the fluorescence intensity was measured at excitation and emission wavelengths of 494 and $519 \mathrm{~nm}$ for fluorophore FAM, 552 and $570 \mathrm{~nm}$ for fluorophore Cy3, and 650 and $670 \mathrm{~nm}$ for fluorophore Cy5, respectively. As shown in Figure 2, the fluorescence intensity in the reaction with 5-FAM/3-BHQ1-labeled substrate continuously increased from 215.33 to a maximum of 1232.15 in $25 \mathrm{~min}$. In the reaction with 5-Cy3/3-BHQ2 and 5-Cy5/3-BHQ2-labeled substrates, the fluorescence intensity increase was less than 2 -fold and reached the maximum in $5 \mathrm{~min}$. The 5-FAM/3-BHQ1 combination showed long-lasting continuous changes in fluorescence and a high fluorescence yield, and was thus the best candidate for further experiments.

\section{Fluorescent Method vs. Gel Electrophoresis}

The traditional agarose gel electrophoresis assay was used to check whether the fluorescence method using the 5-FAM/3BHQ1-labeled 24 bp dsEGFP substrate was suitable for the detection of dsRNA degradation. The serum and gut fluids from

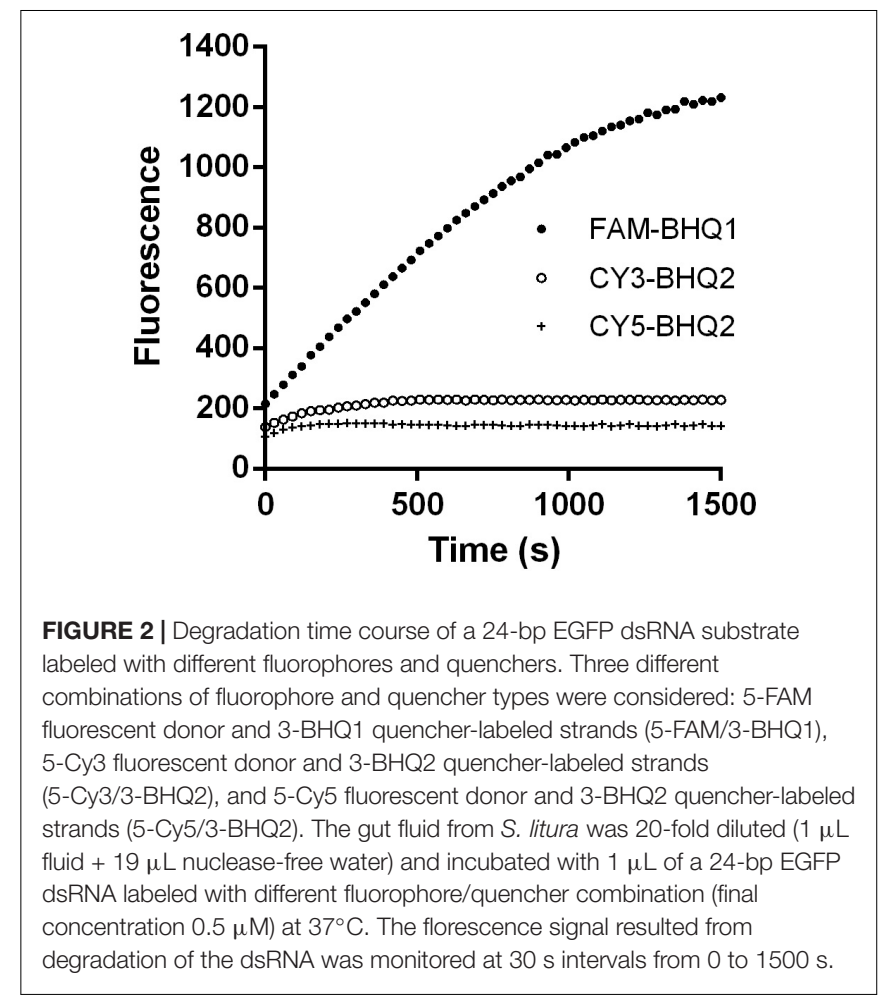

S. litura were incubated with 5-FAM/3-BHQ1-labeled 24 bp dsEGFP, and the reaction was monitored using the fluorescence monitoring method. A parallel control degradation experiment was performed using 414 bp dsEGFP as substrate and the reaction was monitored by checking the residual substrate with gel electrophoresis. As shown in Figure 3, both detection methods yielded similar results. In the reaction with gut fluid, the saturation of fluorescence intensity took about $2100 \mathrm{~s}$ (35 min) and the band of residual dsRNA on the gel disappeared within $30 \mathrm{~min}$. With serum, the fluorescence intensity increased only slightly (less than half the saturation in the gut fluid reaction) over the course of $2 \mathrm{~h}$, and in the parallel experiment for gel electrophoresis method, the band of residual dsEGFP on the gel was still clearly visible after $2 \mathrm{~h}$ of incubation. This result indicated that the newly developed fluorescence method delivered accurate results and was obviously superior to gel electrophoresis, was easier to perform, and could be used for straightforward and reliable quantification of dsRNA.

\section{Fluorescent Method vs. qPCR}

The fluorescence method was also validated by monitoring dsRNA degrading activity of serially diluted gut fluid from S. litura, using a well-accepted qPCR method. The parallel experiments were set up using identical enzyme solutions, but different substrates. As shown in Figure 4, the two methods produced similar curves with a correlation coefficient of 0.976 $(P=0.0009)$. This result further validated the fluorescence method's effectiveness as being similar to that of the qPCR method for detecting dsRNA degrading activity. Moreover, it has the benefit of being a comparatively easier method. 


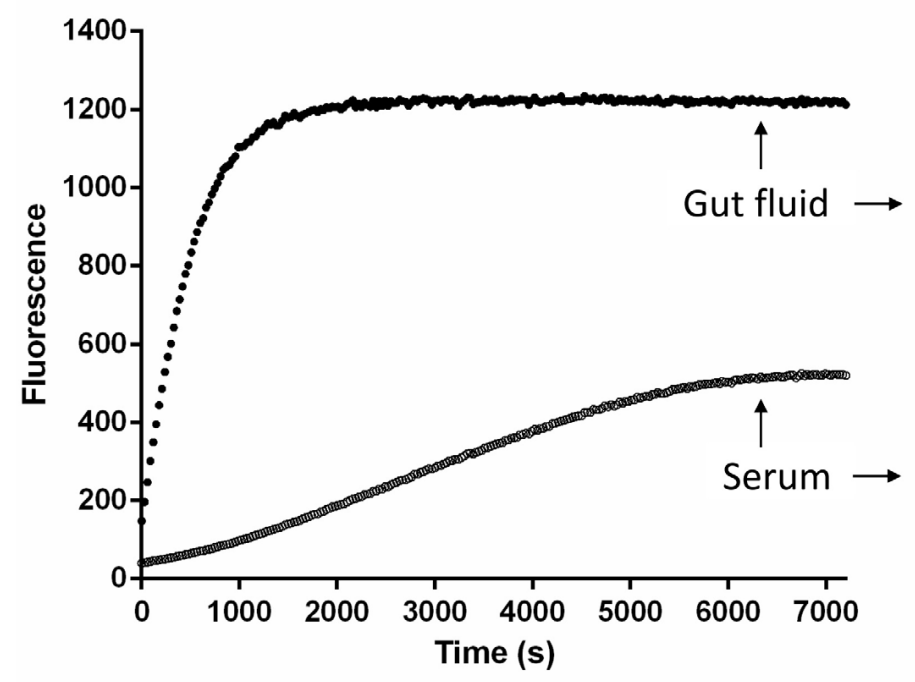

\section{Incubation time ( $\mathrm{min})$}

$\begin{array}{lllllll}M & C K & 2 & 10 & 30 & 60 & 120\end{array}$

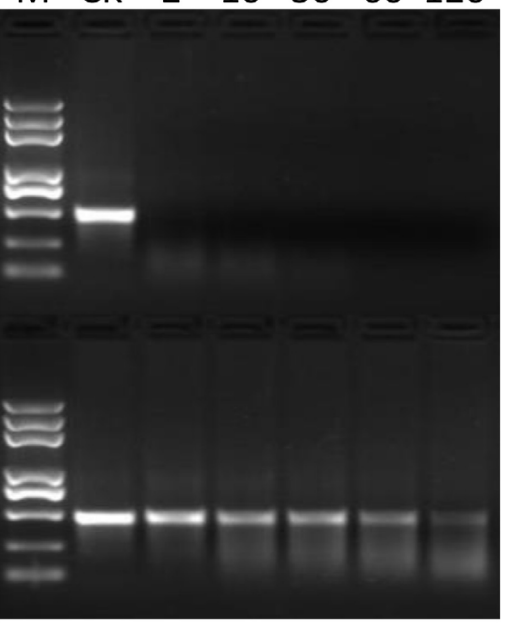

FIGURE 3 | Comparison of fluorescent (Left) and gel electrophoresis (Right) methods for analyzing dsRNA degrading nucleases in S. litura serum and gut fluid. Both serum and gut fluid were diluted 20 times with nuclease free water, and the fluorescence reaction was incubated with 24 bp fluorescence labeled dsEGFP in the final concentration $0.5 \mu \mathrm{M}$. The gel electrophoresis reaction was incubated with $414 \mathrm{bp}$ naked dsEGFP in the final concentration $0.05 \mu \mathrm{g} / \mu \mathrm{L}$. CK: Control without enzymes. M: Trans $2 \mathrm{~K}$ Plus DNA marker. Numbers 2-120 were the minutes indicating sample incubation time.

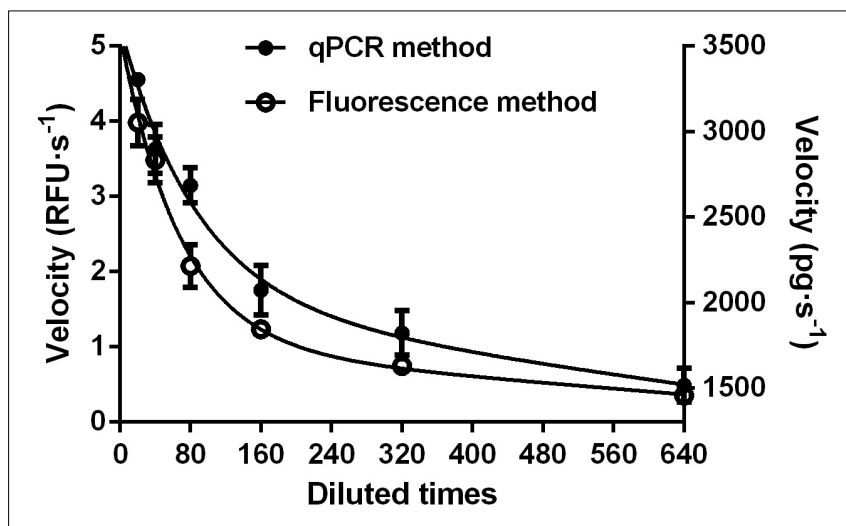

FIGURE 4 | Comparison of fluorescent (Left) and qPCR (Right) methods for analyzing dsRNA degrading nucleases in $S$. litura gut fluid. Serial dilutions of the gut fluid $(20,40,80,160,320$, and 640 times) were incubated with $1 \mu \mathrm{L}$ 24 bp fluorescence labeled dsEGFP or $1 \mu \mathrm{L} 414$ bp naked dsEGFP in a total volume of $20 \mu \mathrm{L}$ at $37^{\circ} \mathrm{C}$. The final substrate concentration was $0.5 \mu \mathrm{M}$ for fluorescence method and $0.05 \mu \mathrm{g} / \mu \mathrm{L}$ for $\mathrm{qPCR}$ method. Values are mean \pm SE; $n=3$.

\section{Biochemical Differences of the dsRNA Degrading Nucleases in Four Insects Impact of $\mathrm{pH}$}

The effect of $\mathrm{pH}$ on dsRNA degrading activity was measured in Glycine-KOH buffer ( $\mathrm{pH}$ 6.5, 7.4, 8.0, 9.0, 10.0, and 11.0). Enzymes from four insect species were tested, and the optimal $\mathrm{pH}$ for three of them was found to be 9.0 (Figure 5). However, the enzyme from S. litura was singular in that it displayed its highest activity at a $\mathrm{pH}$ of 11.0, the upper limit of the test range. This confirmed the assertion that degradation of dsRNA in different insects is alkaline-activated. Besides this, the intimate neighbor relationship between the two curves of $\mathrm{pH} 6.5$ and $\mathrm{pH}$ 7.4 implied that small variations within the neutral $\mathrm{pH}$ range did not overtly influence enzyme activity, and that the influence of $\mathrm{pH}$ was mainly found under alkaline conditions ( $\mathrm{pH} 7.4-11.0)$, highlighting the differences between insects. Other than S. litura, $P$. americana also retained high activity at $\mathrm{pH} 10.0$ and $\mathrm{pH}$ 11.0. However, when $\mathrm{pH}$ exceeded the optimal range $(\mathrm{pH} 9.0)$, activities decreased markedly in the other two insect species, and especially for $Z$. atratus. In the following studies, considering $\mathrm{pH} 11.0$ is extremely alkaline and that dsRNA is structurally unstable under such conditions (Christiaens and Smagghe, 2014), $\mathrm{pH} 10.0$ was used instead of the optimal $\mathrm{pH}$ for the S. litura enzyme.

\section{Impact of $\mathrm{Mg}^{2+}$ Concentration}

Optimization of $\mathrm{Mg}^{2+}$ concentration was conducted at the optimal $\mathrm{pH}$ ( $\mathrm{pH} 10.0$ for S. litura, $\mathrm{pH} 9.0$ for L. migratoria, $P$. americana, and $Z$. atratus) using the reaction buffer containing different concentrations of $\mathrm{MgCl}_{2}$. As shown in Figure 6, an optimal amount of $\mathrm{Mg}^{2+}$ could stimulate dsRNA degrading activity in all four of the insect species tested. The optimal $\mathrm{Mg}^{2+}$ concentration range for dsRNA degrading activity in S. litura and L. migratoria was $0.5-8 \mathrm{mM}$, and for Z. atratus it was $8-32 \mathrm{mM}$. However, no optimal $\mathrm{Mg}^{2+}$ concentration range was found for $P$. americana, whose dsRNA degrading ability slowly increased (by 2 -fold in total) with increasing $\mathrm{Mg}^{2+}$ concentration within the range tested (0-64 mM). Considering the limited changes in activity over a large range of $\mathrm{Mg}^{2+}$ concentrations among different insect enzymes, $8 \mathrm{mM}$ is likely to be an optimal $\mathrm{Mg}^{2+}$ concentration for most insects. 


\section{S. litura}

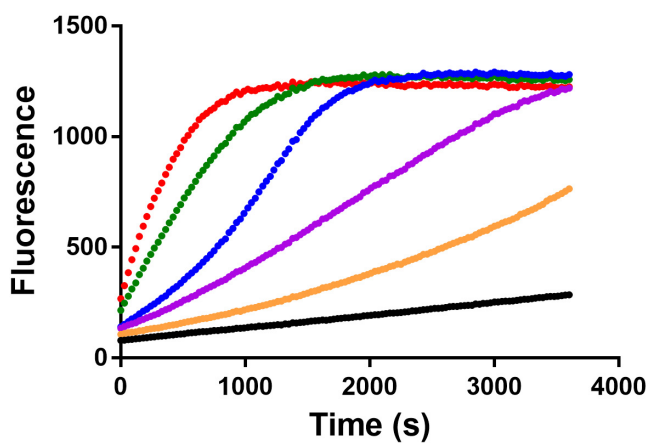

P. americana

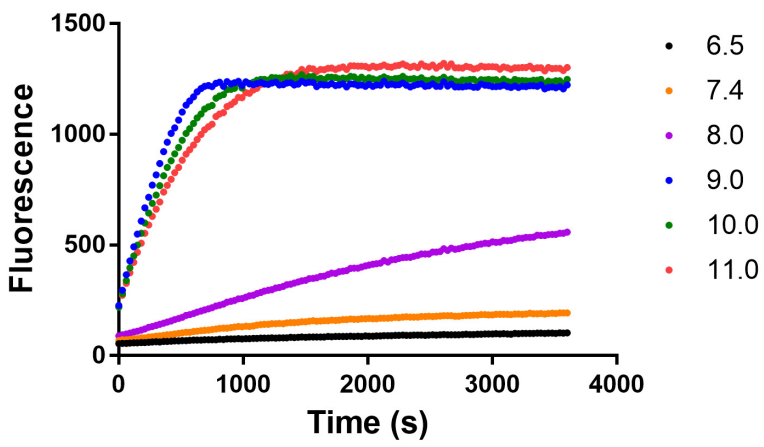

L. migratoria

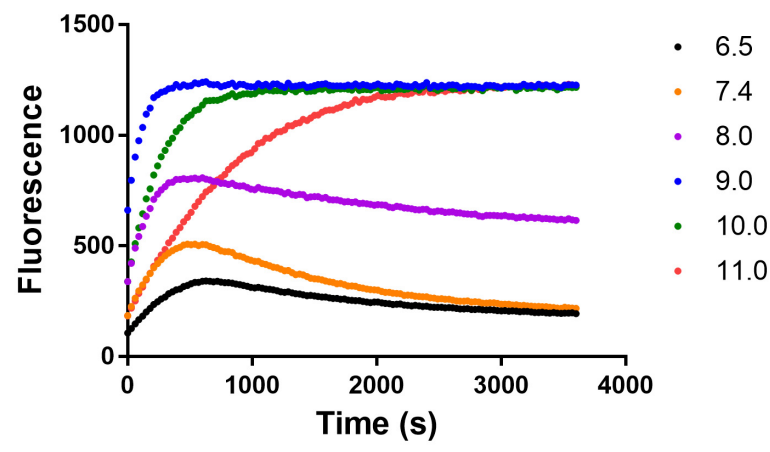

Z. atratus

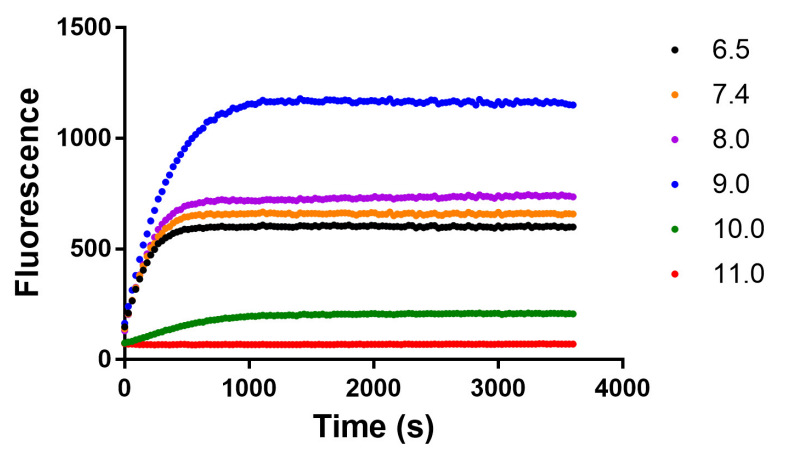

FIGURE 5 | Distinct impacts of pH on the dsRNA degrading nucleases of four insects. The homogenates were prepared from whole body of different insects. The reaction buffer containing $0.1 \mathrm{M}$ Glycine, $0.1 \mathrm{M} \mathrm{NaCl}, 1 \mathrm{mM} \mathrm{MgCl} 2,1 \mathrm{mM} \mathrm{PTU}, 1 \mathrm{mM} \mathrm{DTT}, 1 \mathrm{mM}$ PMSF and $10 \%$ Glycerol was adjusted by KOH to different pH (6.5, 7.4, 8.0, 9.0, 10.0, and 11.0). Each reaction containing $19 \mu \mathrm{L}$ enzyme solution and $1 \mu \mathrm{L}$ fluorescence labeled dsRNA substrate at a final concentration of $0.5 \mu \mathrm{M}$. The fluorescence intensity in different reactions were continuously monitored at $37^{\circ} \mathrm{C}$. Values are mean of fluorescence intensity; $n=3$.

\section{Impact of Temperature}

Suitable reaction temperatures were determined under optimal $\mathrm{pH}$ and $\mathrm{Mg}^{2+}$ concentration conditions $(\mathrm{pH} 10.0$ and $8 \mathrm{mM}$ $\mathrm{Mg}^{2+}$ for S. litura, $\mathrm{pH} 9.0$ and $8 \mathrm{mM} \mathrm{Mg}^{2+}$ for L. migratoria, $P$. americana, and $Z$. atratus). As expected, the initial dsRNA degrading activity increased with temperature at lower temperatures following the well-known temperature effect rule $\left(Q_{10}\right)$, but was inhibited at higher temperatures. In S. litura, L. migratoria, and $P$. americana the activity increased smoothly between 17 and $47^{\circ} \mathrm{C}$, after which the rate of increase slowed down (Figure 7). In $Z$. atratus, the enzyme was extremely sensitive to high temperatures, with the activity dropping sharply above $37^{\circ} \mathrm{C}$. Thus, $37^{\circ} \mathrm{C}$ may be a suitable temperature for higher enzyme activity in most insects. Besides, as shown in Figure 7, the slope of the temperature/activity curve varied in different insect species $\left(Q_{10}\right.$ range: 1.21-1.28). This also means that dsRNA degrading enzymes in different insects may vary marginally in their sensitivity to temperature.

\section{Saturation Curves and Enzyme Kinetics}

The $K_{\mathrm{m}}$ and $V_{\max }$ of dsRNA degrading enzymes from different insect species were calculated using non-linear regression to fit the plot of velocities against substrate concentrations (Figure 8). The enzyme from $P$. americana exhibited high substrate affinity $\left(K_{\mathrm{m}} 0.27 \mu \mathrm{M}\right)$ and low capacity $\left(V_{\max } 3.58 \mu \mathrm{M} \cdot \mathrm{s}^{-1}\right)$. Whereas $Z$. atratus showed low affinity $\left(\begin{array}{llll}K_{\mathrm{m}} & 17.59 & \mu \mathrm{M}\end{array}\right)$ but high capacity $\left(V_{\max } 38.87 \mu \mathrm{M} \cdot \mathrm{s}^{-1}\right)$. The $K_{\mathrm{m}}$ values of $S$. litura and L. migratoria enzymes were 2.28 and $3.06 \mu \mathrm{M}$, respectively, and the corresponding $V_{\max }$ values were $13.40 \mu \mathrm{M} \cdot \mathrm{s}^{-1}$ and $9.46 \mu \mathrm{M} \cdot \mathrm{s}^{-1}$, respectively. For the enzymes from the four insects tested, the $K_{\mathrm{m}}$ values ranked as follows: P. americana $0.27<$ S. litura $2.28 \approx$ L. migratoria $3.06<Z$. atratus 17.59 and the $V_{\max } P$. americana $3.58<$ S. litura $13.4 \approx$ L. migratoria $9.46<Z$. atratus 38.87 , but were of similar order. It appears that different insects maintain proper dsRNA degrading activity by balancing the $K_{\mathrm{m}}$ and $V_{\max }$ of their enzymes.

\section{Differences in the Tissue Distribution of dsRNA Degrading Nucleases Among Four Different Insect Species}

The dsRNA degrading activity in insect whole body, gut, hemolymph and other tissues (carcass) was evaluated in each species at their own experimentally determined optimal 


\section{S.litura}

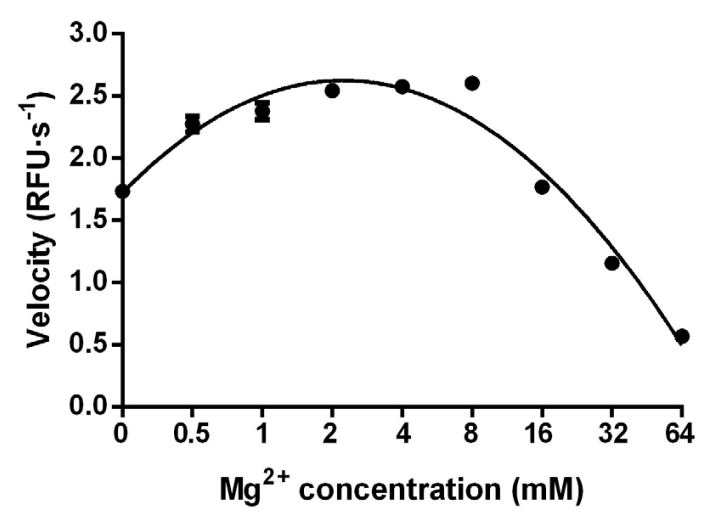

P. americana

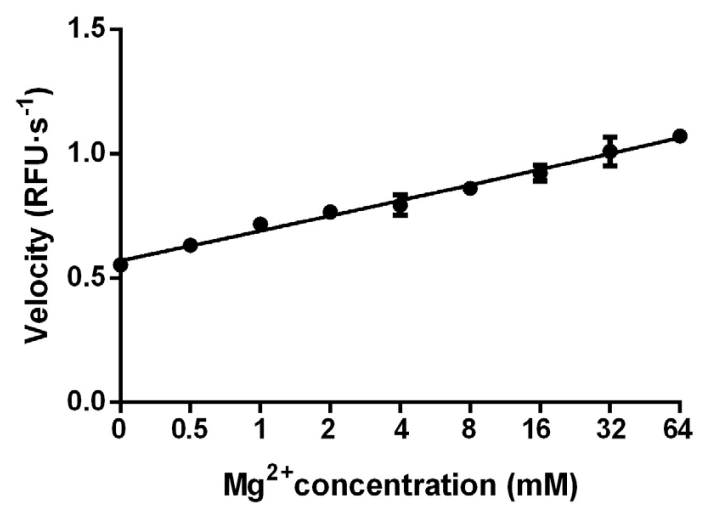

L. migratoria

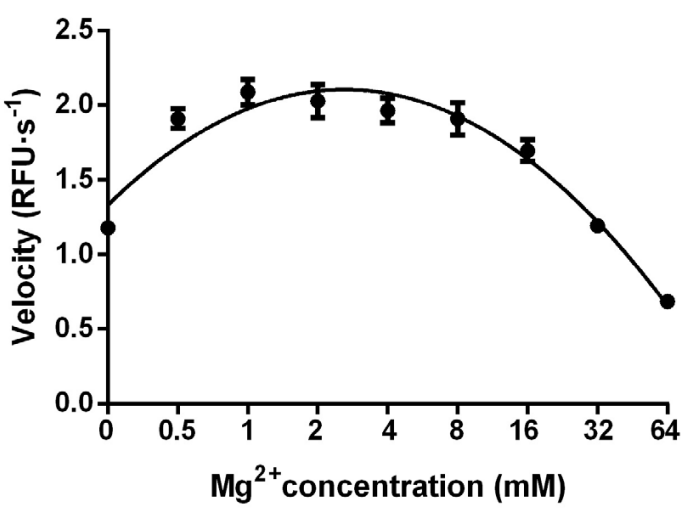

Z. atratus

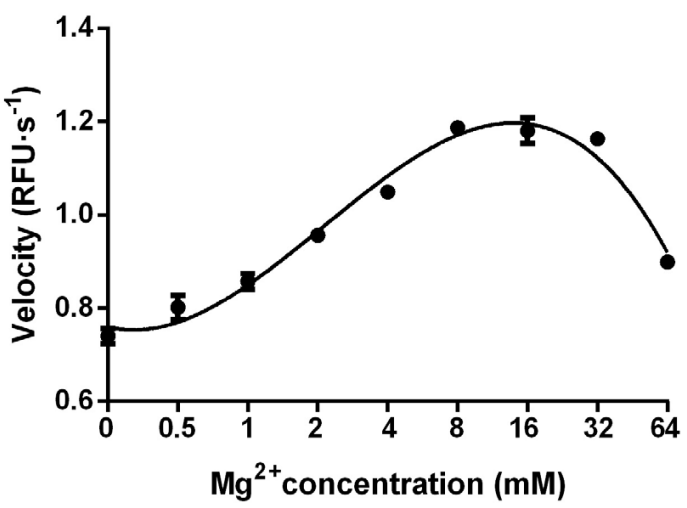

FIGURE 6 | Distinct impacts of $\mathrm{Mg}^{2+}$ concentrations on the dsRNA degrading nucleases of four insects. The homogenates were prepared from whole body of different insects. Tested conditions were conducted under their optimal pH (pH 10.0 for $\mathrm{S}$. litura and pH 9.0 for the other three species). Each reaction containing $19 \mu \mathrm{L}$ enzyme solution and $1 \mu \mathrm{L}$ fluorescence labeled dsRNA substrate at a final concentration of $0.5 \mu \mathrm{M}$. The fluorescence intensity in different reactions were continuously monitored at $37^{\circ} \mathrm{C}$. Values are mean $\pm \mathrm{SE} ; n=3$.

$\mathrm{pH}$ and $\mathrm{Mg}^{2+}$ concentrations. As shown in Table 1, the highest activity was found in gut tissue, and was over 100 fold higher than the activity in hemolymph and carcass in all four of the insect species tested (Table 1). When different insects were compared, whole body activity varied significantly between species. In terms of tissue activity, L. migratoria had extremely high activity in its gut. However, its hemolymph activity was relatively low, being only slightly higher than that of $P$. americana and $Z$. atratus. S. litura not only had higher activity in its gut, but also had much higher activity in its hemolymph than the other insects tested. P. americana had low activity in its gut and very low activity in its hemolymph. Z. atratus had the lowest overall activity in its tissues of all the tested species. Whole body activity of different insects could be ranked in the following order: L. migratoria $>>P$. americana $\geq S$. litura $>>Z$. atratus, which is completely different from their RNAi sensitivities: P. americana $>Z$. atratus $>>L$. migratoria $>>$ S. litura. This inconsistence may result from other factors influencing RNAi efficiency, and also imply that the dsRNA degrading enzymes function in vivo at the conditions different from those we used for activity tests.

\section{Differences in Physiological Conditions Among Four Insect Species}

The $\mathrm{pH}$ and $\mathrm{Mg}^{2+}$ concentration in serum and gut fluids from four insect species were tested. The results presented in Table 2 indicate that these insects differed in terms of their internal chemical environments. Serum $\mathrm{pH}$ appeared neutral with minor variation, ranging from 6.69 to 7.16 , depending on the insect species. The gut fluids of $L$. migratoria, $P$. americana, and Z. atratus were slightly acidic, with $\mathrm{pH}$ ranging from 5.74 to 6.23 . However, the gut fluid of $S$. litura was alkaline with a $\mathrm{pH}$ of 8.72. $\mathrm{Mg}^{2+}$ concentrations in both the serum and gut fluid also varied among the four insect species. S. litura had high serum $\mathrm{Mg}^{2+}(39.37 \mathrm{mM})$, but extremely low gut fluid concentrations (2.75 $\mathrm{mM})$. In comparison, L. migratoria $\mathrm{Mg}^{2+}$ concentration was low in serum (10.68 mM), but high in gut fluid $(40.45 \mathrm{mM})$. 


\section{S.litura}

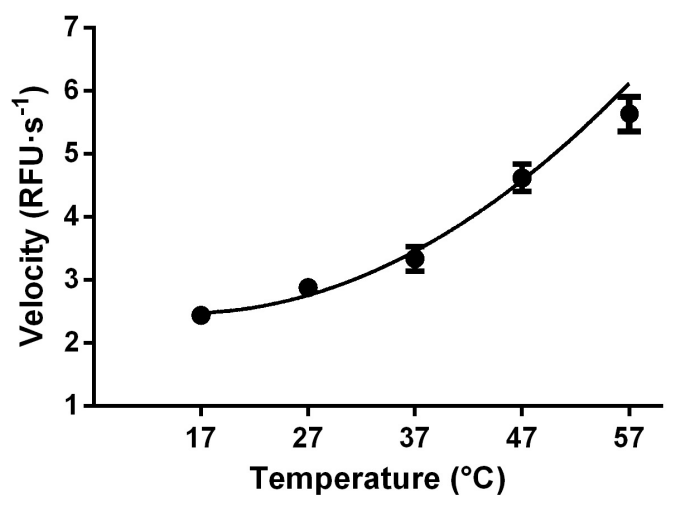

P. americana

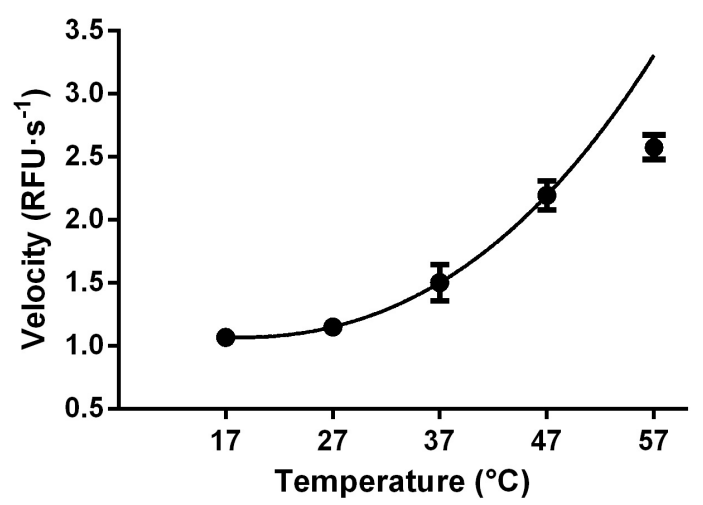

L. migratoria

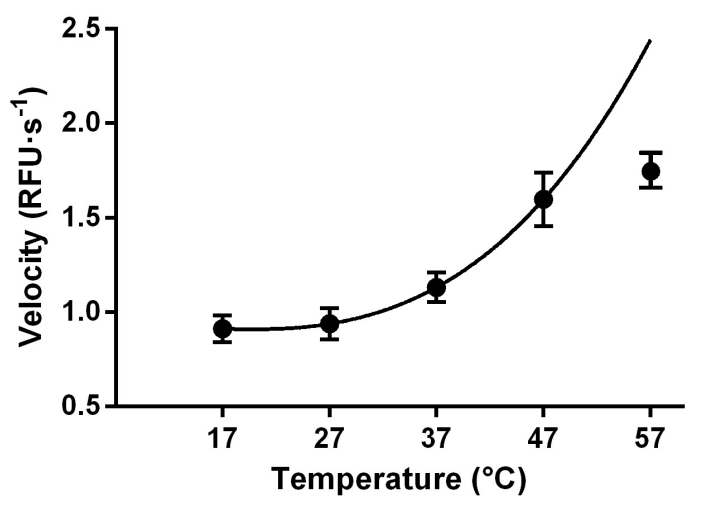

Z. atratus

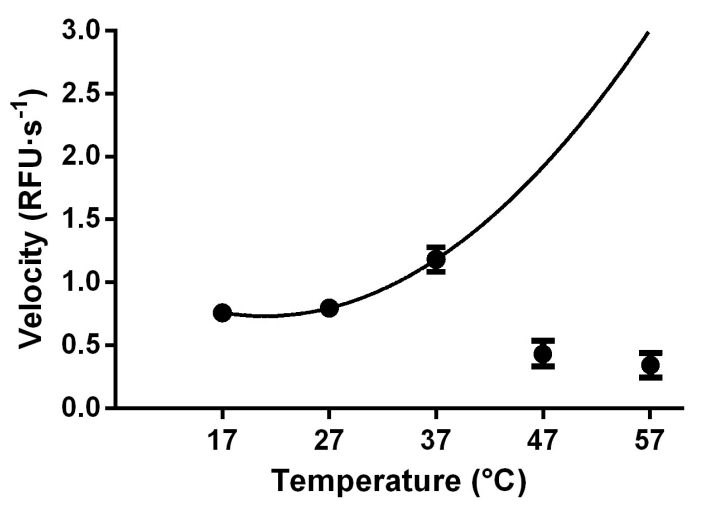

FIGURE 7 | Distinct impacts of temperature on the dsRNA degrading nucleases of four insects. The homogenates were prepared from whole body of different insects. The test reaction used the buffer with optimal $\mathrm{pH}$ and $\mathrm{Mg}^{2+}$ concentrations for different insect species $\left(\mathrm{pH} 10.0\right.$ and 8 mM Mg${ }^{2+}$ for S. litura, $\mathrm{pH} 9.0$ and $8 \mathrm{mM} \mathrm{Mg}^{2+}$ for the other three species). Each reaction containing $19 \mu \mathrm{L}$ enzyme solution and $1 \mu \mathrm{L}$ fluorescence labeled dsRNA substrate at a final concentration of $0.5 \mu \mathrm{M}$. The fluorescence intensity in different reactions were continuously monitored at different temperatures. Values are mean \pm SE; $n=3$.

$P$. americana was found to have low $\mathrm{Mg}^{2+}$ concentrations in both its serum $(4.64 \mathrm{mM})$ and gut fluid $(11.39 \mathrm{mM})$. For $Z$. atratus, high $\mathrm{Mg}^{2+}$ concentration was found in both serum $(35.36 \mathrm{mM})$ and gut fluid $(42.54 \mathrm{mM})$. Neither the serum nor the gut fluids of any of the insects tested were optimal for in vitro dsRNA degradation when both $\mathrm{pH}$ and $\mathrm{Mg}^{2+}$ concentrations were taken into consideration.

\section{Comparison of the Optimal and Physiological Activity of dsRNA Degrading Nucleases Among Four Different Insects}

The serums and gut fluids of different insects were compared in terms of their dsRNA degrading activity under physiological and optimal $\mathrm{pH}$ and $\mathrm{Mg}^{2+}$ concentration conditions. The results in Table 3 clearly show that both gut fluids and serums from different insect species exhibited much lower dsRNA degrading activities under physiological conditions than under their respective optimal conditions in most cases (4.5-378.2-fold differences). However, the gut fluid of S. litura (1.6-fold) and the serum of $Z$. atratus (1.0-fold) did not notably deplete degradative activity. Correspondingly, the $\mathrm{pH}$ in the gut fluid of $S$. litura was higher than in other species, and the $\mathrm{Mg}^{2+}$ concentration in the serum of $Z$. atratus was extremely high.

\section{DISCUSSION}

In this study, the continuous fluorescence intensity measurement method developed by Podolska et al. (2014) for Dicer cleavage assays was adopted and modified for monitoring dsRNA degrading activity. Owing to different combinations of fluorophores and quenchers with varying fluorescent intensity (Podolska et al., 2014), selection experiments were performed, which found 5-FAM fluorescent donor- and 3-BHQ1 quencherlabeled 24 bp dsRNA to be the most sensitive substrate. With this substrate, the fluorescence method was validated using traditional gel electrophoresis and a well-accepted microquantitative PCR method. The monitoring of dsRNA degrading 
S.litura

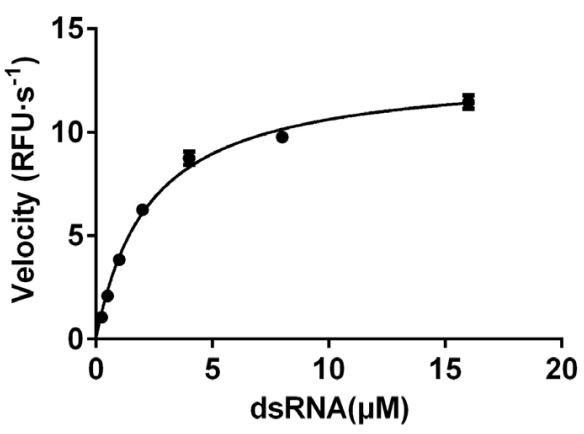

P. americana

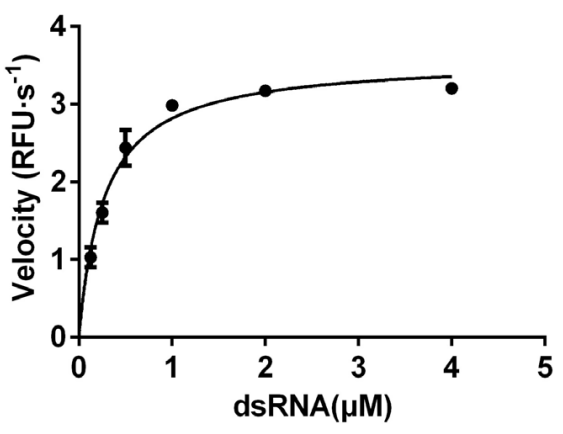

L. migratoria

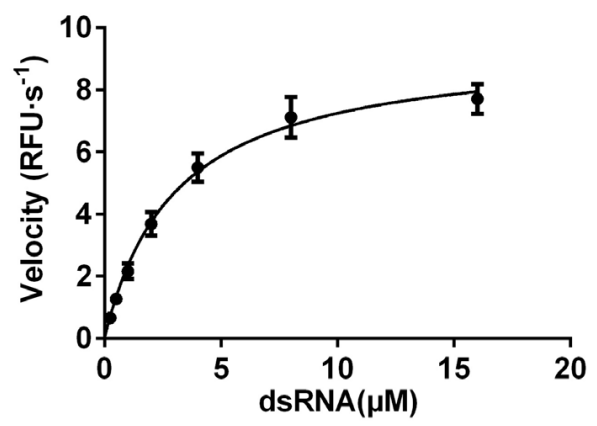

Z. atratus

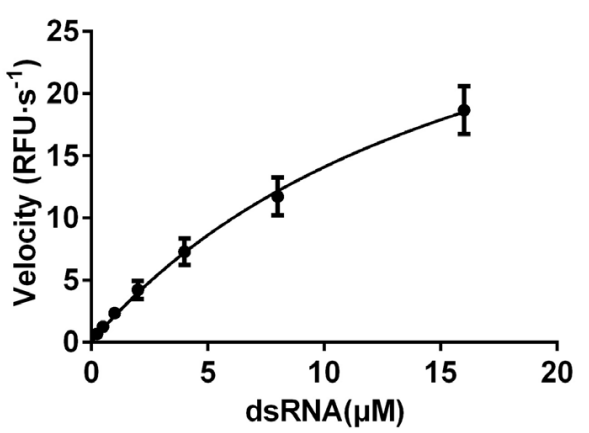

FIGURE 8 | Comparison of the saturation curves of the dsRNA degrading nuclease of four insects. The homogenates were prepared from whole body of different insects. The test reaction used the buffer with optimal $\mathrm{pH}$ and $\mathrm{Mg}^{2+}$ concentrations for different insect species $\left(\mathrm{pH} 10.0\right.$ and $8 \mathrm{mM} \mathrm{Mg}{ }^{2+}$ for S. litura, $\mathrm{pH} 9.0$ and $8 \mathrm{mM} \mathrm{Mg}^{2+}$ for the other three species). Different concentration of dsRNA substrates were incubated with $19 \mu \mathrm{L}$ enzyme solutions in a total volume of $20 \mu \mathrm{L}$. The fluorescence intensity in different reactions were continuously monitored at $37^{\circ} \mathrm{C}$. Values are mean $\pm \mathrm{SE} ; n=3$.

activity in different insect tissues and series dilutions of gut fluid all showed that the fluorescence method gave reliable results. Furthermore, the fluorescence method is easier to execute than the qPCR method, and more accurate than gel electrophoresis.

With the developed fluorescence method, dsRNA degrading activities in different insects were tested and their characteristics compared. The results clearly showed that insect dsRNA degrading nucleases are basophilic with an optimal $\mathrm{pH}$ of 9.0 or more. Furthermore, optimal $\mathrm{Mg}^{2+}$ ion concentrations enhanced the activity of nucleases in all of the insect species tested. These results were consistent with previous reports in which purified dsRNase from the digestive juice of Bombyx mori (BmdsRNase), and expressed recombinant LmdsRNase2 from L. migratoria, were both found to have higher activities under alkaline conditions (Arimatsu et al., 2007a; Song et al., 2017), which were further promoted by addition of divalent cations (Arimatsu et al., 2007a). Furthermore, our results showed that the enzymes' optimal $\mathrm{pH}, \mathrm{Mg}^{2+}$ concentration range, and temperature varied with insect species. Enzymes from S. litura, a defoliator feeding on alkaline food, had the highest optimal $\mathrm{pH}$. BmdsRNase from another lepidopteran defoliator has been reported to also have $\mathrm{pH}$-dependent activity (Arimatsu et al., 2007a). The enzyme from $Z$. atratus, a store grain pest living in shedding rooms, was highly sensitive to high temperatures, and its activity was greatly inhibited above $37^{\circ} \mathrm{C}$. For the other insects living in open air, enzymes were inhibited at temperatures higher than $47^{\circ} \mathrm{C}$. It appears that different insects produce diverse dsRNA degrading enzymes with different properties. Whether these properties are coupled with their habitats requires further investigation.

The different kinetic parameters of enzymes, tested under the optimal conditions of each enzyme, not only provided further confirmation that different insects produce different nucleic acid degrading enzymes, but also demonstrated that they produce them in different quantities. The characteristic parameter of enzymes, $K_{\mathrm{m}}$, was found to differ in enzymes from $P$. americana $(0.27 \mu \mathrm{M})$, S. litura $(2.28 \mu \mathrm{M})$, L. migratoria (3.06 $\mu \mathrm{M})$, and $Z$. atratus $(17.59 \mu \mathrm{M})$. Although tested with whole body extracts, and as a weighted average integrating all enzymes, the variation in $K_{\mathrm{m}}$ could indicate different production profiles for nucleic acid degrading enzymes in each insect. Consistent with this finding, previous identification of gutspecific double-stranded RNA degrading enzymes proved that the dsRNase activity was mostly attributable to genes encoding DNA/RNA non-specific endonuclease family enzymes (Wynant et al., 2014). The knockdown effect of dsRNA degrading nuclease activity in different insects also demonstrated the existence of a variety of enzymes in different insects (Luo et al., 2017; Song et al., 2017; Spit et al., 2017). $V_{\max }$ is a parameter depending on the enzyme protein concentration. Thus, different 


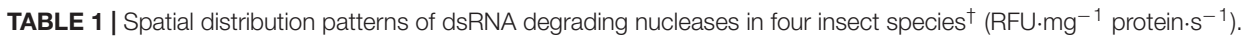

\begin{tabular}{|c|c|c|c|c|}
\hline Insects & Whole body & Gut & Hemolymph & Carcass \\
\hline Spodoptera litura & $28.2 \pm 8.4^{b}$ & $1767.1 \pm 371.5^{\mathrm{b}}$ & $8.8 \pm 0.3^{a}$ & $0.9 \pm 0.2^{b}$ \\
\hline Locusta migratoria & $3019.4 \pm 25.5^{a}$ & $119081.8 \pm 10596.1^{a}$ & $0.4 \pm 0.1^{b}$ & $218.7 \pm 6.8^{a}$ \\
\hline Periplaneta americana & $48.1 \pm 16.9^{b}$ & $756.4 \pm 122.1^{c}$ & $0.13 \pm 0.01^{c}$ & $1.2 \pm 0.3^{b}$ \\
\hline Zophobas atratus & $8.5 \pm 1.7^{c}$ & $34.66 \pm 3.98^{d}$ & $0.13 \pm 0.05^{c}$ & $0.28 \pm 0.05^{c}$ \\
\hline
\end{tabular}

†Tested under optimal $\mathrm{pH}$ and $\mathrm{Mg}^{2+}$ concentrations for each insect species. $\mathrm{pH} 10.0$ and $8 \mathrm{mM} \mathrm{Mg}^{2+}$ for S. litura, pH 9.0 and $8 \mathrm{mM} \mathrm{Mg}{ }^{2+}$ for the other three. Different letters $(a, b, c, d)$ indicate significant differences among insects $(P<0.05)$. Values are mean $\pm S D ; n=3$.

TABLE 2 | Measurements of $\mathrm{pH}$ values and $\mathrm{Mg}^{2+}$ concentrations in the gut lumen and hemolymph of four insect species.

\begin{tabular}{|c|c|c|c|c|}
\hline \multirow[t]{2}{*}{ Insects } & \multicolumn{2}{|c|}{$\mathrm{pH}$} & \multicolumn{2}{|c|}{$\mathrm{Mg}^{2+}(\mathrm{mM})$} \\
\hline & Serum & Gut fluid & Serum & Gut fluid \\
\hline Spodoptera litura & $6.69 \pm 0.02^{b}$ & $8.72 \pm 0.12^{a}$ & $39.37 \pm 0.94^{a}$ & $2.75 \pm 0.19^{c}$ \\
\hline Locusta migratoria & $6.82 \pm 0.20^{b}$ & $5.79 \pm 0.25^{\mathrm{c}}$ & $10.68 \pm 0.47^{c}$ & $40.45 \pm 1.37^{a}$ \\
\hline Periplaneta americana & $7.16 \pm 0.13^{a}$ & $6.23 \pm 0.08^{b}$ & $4.64 \pm 0.23^{d}$ & $11.39 \pm 0.64^{b}$ \\
\hline Zophobas atratus & $6.84 \pm 0.09^{b}$ & $5.74 \pm 0.04^{c}$ & $35.36 \pm 1.37^{b}$ & $42.54 \pm 2.53^{a}$ \\
\hline
\end{tabular}

Different letters $(a, b, c, d)$ indicate significant differences among insects $(P<0.05)$. Values are mean $\pm S D ; n=3$.

TABLE 3 | Comparison of the optimal and physiological dsRNA nuclease activity in the gut lumen and hemolymph of four insect species $\left(\right.$ RFU $\mathrm{mg}^{-1}$ protein $^{-1} \mathrm{~S}^{-1}$.

\begin{tabular}{|c|c|c|c|c|c|c|}
\hline \multirow[t]{2}{*}{ Insects } & \multicolumn{3}{|c|}{ Gut fluid } & \multicolumn{3}{|c|}{ Serum } \\
\hline & Optimal $^{\dagger}$ & Physiological ${ }^{\ddagger}$ & Ratio $\$$ & Optimal & Physiological & Ratio \\
\hline Spodoptera litura & $11364.1 \pm 777.3^{\mathrm{b}}$ & $6923.6 \pm 109.8^{a}$ & 1.6 & $30.40 \pm 8.72^{\mathrm{a}}$ & $0.80 \pm 0.20^{a}$ & 38.0 \\
\hline Locusta migratoria & $18666.3 \pm 3580.9^{a}$ & $49.36 \pm 2.62^{b}$ & 378.2 & $4.47 \pm 0.79^{b}$ & $0.66 \pm 0.30^{a}$ & 6.8 \\
\hline Periplaneta americana & $1674.1 \pm 68.8^{\mathrm{C}}$ & $54.72 \pm 3.68^{b}$ & 30.6 & $1.62 \pm 1.16^{\mathrm{c}}$ & $0.12 \pm 0.04^{b}$ & 13.5 \\
\hline Zophobas atratus & $71.50 \pm 3.99^{d}$ & $15.72 \pm 1.29^{c}$ & 4.5 & $0.04 \pm 0.02^{d}$ & $0.04 \pm 0.01^{c}$ & 1.0 \\
\hline
\end{tabular}

†Tested under the optimal $\mathrm{pH}$ and $\mathrm{Mg}^{2+}$ concentrations for each insect species. $\mathrm{pH} 10.0$ and $8 \mathrm{mM} \mathrm{Mg}^{2+}$ for $\mathrm{S}$. litura, and pH 9.0 and $8 \mathrm{mM} \mathrm{Mg}{ }^{2+}$ for the other three.

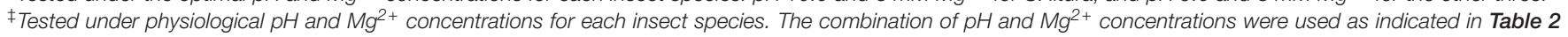
for gut fluid or serum.

${ }^{\S}$ Fold changes of enzyme activity under optimal condition against physiological condition.

Different letters $(a, b, c, d)$ indicate significant differences among insects $(P<0.05)$. Values are mean $\pm S D ; n=3$.

$V_{\max }$ values displayed by the enzymes of different insects (P. americana $3.58 \mu \mathrm{M} \cdot \mathrm{s}^{-1}$, S. litura $13.4 \mu \mathrm{M} \cdot \mathrm{s}^{-1}$, L. migratoria $9.46 \mu \mathrm{M} \cdot \mathrm{s}^{-1}$ and $Z$. atratus $38.87 \mu \mathrm{M} \cdot \mathrm{s}^{-1}$ ) might indicate that these insects had different enzyme concentrations in their bodies. An interesting observation was that, among different insects, higher enzyme affinity (lower $K_{\mathrm{m}}$ ) was usually accompanied with lower enzyme quantity (lower $V_{\max }$ ). It seems this is an evolutionary adaptation for maintaining enzyme activity at the required level.

Whole-body dsRNA degrading activities measured under optimal conditions ( $\mathrm{pH}$ and $\mathrm{Mg}^{2+}$ concentrations) did not correspond well to previously reported RNAi sensitivities (Wang et al., 2016). Previous work showed that P. americana and $Z$. atratus were both equally sensitive to injection and ingestion RNAi; L. migratoria was sensitive to injection RNAi, but not to ingestion; and S. litura was insensitive to both injection and ingestion RNAi (Wang et al., 2016). The order of gut activity, L. migratoria $>>$ S. litura $>P$. americana $>>Z$. atratus, was a slightly better indicator of their susceptibility to ingestion RNAi. Insects' hemolymph activity,
S. litura $>>$ L. migratoria $>P$. americana $\approx Z$. atratus, was comparable to their injection RNAi sensitivity. These results indicated that whole-body activity was not a good indicator for RNAi efficiency, but that hemolymph and gut fluid activities are acceptable indicators for injection and ingestion RNAi, respectively. Data showed that the dsRNA-degrading activity in tissues which contact the delivered dsRNA first was much higher than whole-body activity. This means that the gut is important for degradation of ingested dsRNA, and hemolymph, for injected dsRNA. This is consistent with previous reports (Luo et al., 2013; Wang et al., 2016). However, RNAi efficiency is not totally dependent on dsRNA permanence. Though little evidence was obtained, the sensitivity of RNAi core machinery and dsRNA transportation might involve (Tomoyasu et al., 2008; Huvenne and Smagghe, 2010). Otherwise, we analyzed the enzymes with the data tested in vitro, finding that they may work optimally under different conditions.

Therefore, we measured the $\mathrm{pH}$ and $\mathrm{Mg}^{2+}$ concentrations in the gut lumen and hemolymph of the four insects, finding that their $\mathrm{pH}$ and $\mathrm{Mg}^{2+}$ concentrations were not optimal for 
their dsRNA degrading enzymes. Our work has demonstrated that insect dsRNA degrading enzymes are basophilic. However, in most insect species, hemolymph $\mathrm{pH}$ commonly ranges from neutral to slightly acidic (Wyatt, 1961). Here the tested hemolymph $\mathrm{pH}$ in four insect species ranged from 6.69 to 7.16. This means that the $\mathrm{pH}$ of hemolymph could place limitations on high enzyme activity, and its narrow near-neutral variable range had a negligible effect on dsRNA degrading activity, as the results indicated. The varied $\mathrm{Mg}^{2+}$ concentrations may play a relatively greater role in regulation of enzyme activity in hemolymph. The $\mathrm{pH}$ of insect midguts is reported to range widely from acidic to alkaline (Johnson and Felton, 1996). Our results showed that the gut fluids of L. migratoria, P. americana, and $Z$. atratus were typically acidic to neutral. In the caterpillar $S$. litura, the $\mathrm{pH}$ was extremely alkaline, reaching $\mathrm{pH}$ 8.72. Thus, dsRNA degrading activity of $S$. litura extract tested at gut fluid $\mathrm{pH}$ was similar to that at optimal $\mathrm{pH}$, while activities in the other three insects were depressed dramatically. These findings imply that physiological reaction conditions can regulate dsRNA degrading activity in various insects, and modify their RNAi sensitivity.

Tissue activities in the four insect species tested under physiological conditions were not better correlated with RNAi efficacy than when tested under optimal conditions. P. americana and L. migratoria had similar physiologically tested gut fluid activities, and S. litura and L. migratoria had similar physiologically tested serum activities. This implies that the activities tested in prepared serum and gut fluids are not proportional to the negative dsRNA degrading activities naturally occurring in hemolymph and gut tissues. Previous work has reported that the dsRNA degrading activity of gut fluid may come primarily from excreted dsRNases and should repress RNAi (Almeida Garcia et al., 2017; Luo et al., 2017; Song et al., 2017; Spit et al., 2017). However, gut structure differs between insect species, and especially between those with different feeding habits. It has been established that insect guts vary in terms of $\mathrm{pH}$ and chemical environment in areas such as foregut, midgut, hindgut, and their various subdivided chambers. Thus, activities tested in a composite gut fluid mixture cannot accurately represent the true degradation happening in the gut. Thus, the phytophagous locust and the omnivorous cockroach showed different ingestion RNAi sensitivity, despite their dsRNA degrading activity tested in gut fluid under physiological conditions being similar. Serum should be more uniform because of its quick circulation. However, little is known about dsRNA degrading enzymes in serum. Based on good consistency of injection RNAi efficacy, we deduced that the activities in serum might also come mainly from dsRNases. However, we could not rule out the possibility of participation by other, unknown, enzymes. Rapid cellular absorption may be another influencing factor because all insect organs float in the serum. That explains why the serum dsRNase activity was not exactly consistent with injection RNAi tendency among different insect species. As is generally known, $\mathrm{pH}$ and $\mathrm{Mg}^{2+}$ concentrations vary not only among tissues of different insects, but also in the various subcellular spaces, such as lysosomes and vacuoles, in individual insects. This phenomenon might indicate another regulation mechanism for dsRNA degrading activity, and this regulation seemed so delicate that it was difficult to determine an appropriate activity parameter for describing the exact RNAi sensitivities of different insects.

It should be noted that homogenate supernatants contain a variety of dsRNA degrading enzymes, and that their activities and characteristics should therefore be integrated using a weighted average. The obtained data clearly indicated that all insects tested showed dsRNA degrading activity in their gut which was orders of magnitude higher than in other tested tissues, and this affected the baseline activity for their whole bodies. This indicates that overexpression of dsRNases in the gut lumen is a major negative regulator of the RNAi machinery. This observation has been universally reported in all insect species studied previously (Arimatsu et al., 2007b; Liu et al., 2012; Wynant et al., 2014; Luo et al., 2017; Song et al., 2017; Spit et al., 2017). Thus, our results might reflect the activities and characteristics of dsRNases overexpressed in the gut, although Dicers and other enzymes encoded by unidentified genes may also contribute to the observed effects. The major dsRNases over-expressed in the gut may be key in RNAi efficiency and should be the focus of future studies.

Along with the development of our fluorescence method, we have conducted a comprehensive analysis of the biochemical properties of dsRNA degrading nucleases in four insect species from different orders. Our results revealed the special properties of insect dsRNA degrading enzymes and demonstrated that different insects produce a variety of dsRNA degrading enzymes in different quantities. Furthermore, insects had different physiological conditions in different tissues, which served to modulate enzyme activity. The RNAi tolerance of caterpillar $S$. litura not only resulted from quantitative production of dsRNA degrading enzymes, but also from the alkaline environment of its gut. dsRNA degrading activity may be used to estimate RNAi sensitivity among different insect species, but its use is hindered by the fact that the various methods for testing activity do not precisely mirror the natural physiological conditions found within insects, even ignoring other potentially confounding factors.

\section{AUTHOR CONTRIBUTIONS}

$\mathrm{YP}, \mathrm{KW}$, and $\mathrm{ZH}$ designed the research and wrote the paper. YP performed all of the experiments with the help of WF and CS. YP and $\mathrm{ZH}$ analyzed the data. All authors read and approved the final manuscript.

\section{FUNDING}

This work was supported by the National Natural Science Foundation of China (31672053), the Special Fund for Agroscientific Research in the Public Interest of China (201303017), and a grant (No. 2013) from the Innovation Team Program for Jiangsu Universities.

\section{ACKNOWLEDGMENTS}

We thank Qi Han and Longji Ze for help with insect rearing. 


\section{REFERENCES}

Allen, M. L., and Walker, W. B. (2012). Saliva of Lygus lineolaris digests double stranded ribonucleic acids. J. Insect Physiol. 58, 391-396. doi: 10.1016/j.jinsphys. 2011.12.014

Almeida Garcia, R., Lima Pepino Macedo, L., Cabral do Nascimento, D., Gillet, F.X., Moreira-Pinto, C. E., Faheem, M., et al. (2017). Nucleases as a barrier to gene silencing in the cotton boll weevil, Anthonomus grandis. PLoS One 12:e189600. doi: 10.1371/journal.pone.0189600

Arimatsu, Y., Furuno, T., Sugimura, Y., Togoh, M., Ishihara, R., Tokizane, M., et al. (2007a). Purification and properties of double-stranded RNA-degrading nuclease, dsRNase, from the digestive juice of the silkworm, Bombyx mori. J. Insect Biotechnol. Sericol. 76, 57-62.

Arimatsu, Y., Kotani, E., Sugimura, Y., and Furusawa, T. (2007b). Molecular characterization of a cDNA encoding extracellular dsRNase and its expression in the silkworm, Bombyx mori. Insect Biochem. Mol. Biol. 37, 176-183. doi: 10.1016/j.ibmb.2006.11.004

Baum, J. A., Bogaert, T., Clinton, W., Heck, G. R., Feldmann, P., Ilagan, O., et al. (2007). Control of coleopteran insect pests through RNA interference. Nat. Biotechnol. 25, 1322-1326. doi: 10.1038/nbt1359

Bellés, X. (2010). Beyond Drosophila: RNAi in vivo and functional genomics in insects. Annu. Rev. Entomol. 55, 111-128. doi: 10.1146/annurev-ento-112408085301

Burand, J. P., and Hunter, W. B. (2013). RNAi: future in insect management. J. Invertebr. Pathol. 112, S68-S74. doi: 10.1016/j.jip.2012.07.012

Christiaens, O., and Smagghe, G. (2014). The challenge of RNAi-mediated control of hemipterans. Curr. Opin. Insect Sci. 6, 15-21. doi: 10.1016/j.cois.2014.09.012

Christiaens, O., Swevers, L., and Smagghe, G. (2014). DsRNA degradation in the pea aphid (Acyrthosiphon pisum) associated with lack of response in RNAi feeding and injection assay. Peptides 53, 307-314. doi: 10.1016/j.peptides.2013. 12.014

Fire, A., Xu, S., Montgomery, M. K., Kostas, S. A., Driver, S. E., and Mello, C. C. (1998). Potent and specific genetic interference by double-stranded RNA in Caenorhabditis elegans. Nature 391, 806-811. doi: 10.1038/35888

Furusawa, T., Takayama, E., Ishihara, R., and Hayashi, Y. (1993). Double-stranded ribonuclease activity in the digestive juice and midgut of the silkworm, Bombyx mori. Comp. Biochem. Physiol. 104, 795-801. doi: 10.1016/0305-0491(93) 90215-Q

Garbutt, J. S., Bellés, X., Richards, E. H., and Reynolds, S. E. (2013). Persistence of double-stranded RNA in insect hemolymph as a potential determiner of RNA interference success: evidence from Manduca sexta and Blattella germanica. J. Insect Physiol. 59, 171-178. doi: 10.1016/j.jinsphys.2012.05.013

Ghosh, S., Kakumani, P. K., Kumar, A., Malhotra, P., Mukherjee, S. K., and Bhatnagar, R. K. (2014). Genome wide screening of RNAi factors of Sf21 cells reveal several novel pathway associated proteins. BMC Genomics 15:775. doi: 10.1186/1471-2164-15-775

Han, B. W., Hung, J.-H., Weng, Z., Zamore, P. D., and Ameres, S. L. (2011). The $3^{\prime}$-to- $5^{\prime}$ exoribonuclease Nibbler shapes the $3^{\prime}$ ends of microRNAs bound to Drosophila Argonaute1. Curr. Biol. 21, 1878-1887. doi: 10.1016/j.cub.2011. 09.034

Harrison, J. F. (2001). Insect acid-base physiology. Annu. Rev. Entomol. 46, 221-250. doi: 10.1146/annurev.ento.46.1.221

Huvenne, H., and Smagghe, G. (2010). Mechanisms of dsRNA uptake in insects and potential of RNAi for pest control: a review. J. Insect Physiol. 56, 227-235. doi: 10.1016/j.jinsphys.2009.10.004

Ivashuta, S., Zhang, Y., Wiggins, B. E., Ramaseshadri, P., Segers, G. C., Johnson, S., et al. (2015). Environmental RNAi in herbivorous insects. RNA 21, 840-850. doi: 10.1261/rna.048116.114

Joga, M. R., Zotti, M. J., Smagghe, G., and Christiaens, O. (2016). RNAi efficiency, systemic properties, and novel delivery methods for pest insect control: what we know so far. Front. Physiol. 7:553. doi: 10.3389/fphys.2016.00553

Johnson, K. S., and Felton, G. W. (1996). Potential influence of midgut pH and redox potential on protein utilization in insect herbivores. Arch. Insect Biochem. Physiol. 32, 85-105. doi: 10.1002/(SICI)1520-6327(1996)32:1<85:: AID-ARCH6>3.0.CO;2-W

Kennedy, S., Wang, D., and Ruvkun, G. (2004). A conserved siRNA-degrading RNase negatively regulates RNA interference in C. elegans. Nature 427, 645-649. doi: $10.1038 /$ nature 02302
Kola, V. S., Renuka, P., Madhav, M. S., and Mangrauthia, S. K. (2015). Key enzymes and proteins of crop insects as candidate for RNAi based gene silencing. Front. Physiol. 6:119. doi: 10.3389/fphys.2015.00119

Kupsco, J. M., Wu, M.-J., Marzluff, W. F., Thapar, R., and Duronio, R. J. (2006). Genetic and biochemical characterization of Drosophila Snipper: a promiscuous member of the metazoan $3^{\prime}$ hExo/ERI-1 family of $3^{\prime}$ to $5^{\prime}$ exonucleases. RNA 12 , 2103-2117. doi: 10.1261/rna.186706

Liu, J., Smagghe, G., and Swevers, L. (2013). Transcriptional response of BmToll91 and RNAi machinery genes to exogenous dsRNA in the midgut of Bombyx mori. J. Insect Physiol. 59, 646-654. doi: 10.1016/j.jinsphys.2013.03.013

Liu, J., Swevers, L., Iatrou, K., Huvenne, H., and Smagghe, G. (2012). Bombyx mori DNA/RNA non-specific nuclease: expression of isoforms in insect culture cells, subcellular localization and functional assays. J. Insect Physiol. 58, 1166-1176. doi: 10.1016/j.jinsphys.2012.05.016

Lomate, P. R., and Bonning, B. C. (2016). Distinct properties of proteases and nucleases in the gut, salivary gland and saliva of southern green stink bug, Nezara viridula. Sci. Rep. 6:27587. doi: 10.1038/srep27587

Luo, Y., Chen, Q., Luan, J., Chung, S. H., Van Eck, J., Turgeon, R., et al. (2017). Towards an understanding of the molecular basis of effective RNAi against a global insect pest, the whitefly Bemisia tabaci. Insect Biochem. Mol. Biol. 88, 21-29. doi: 10.1016/j.ibmb.2017.07.005

Luo, Y., Wang, X., Wang, X., Yu, D., Chen, B., and Kang, L. (2013). Differential responses of migratory locusts to systemic RNA interference via doublestranded RNA injection and feeding: RNAi in the migratory locust. Insect Mol. Biol. 22, 574-583. doi: 10.1111/imb.12046

Marques, J. T., Wang, J.-P., Wang, X., de Oliveira, K. P., Gao, C., Aguiar, E. R., et al. (2013). Functional specialization of the small interfering RNA pathway in response to virus infection. PLoS Pathog. 9:e1003579. doi: 10.1371/journal.ppat. 1003579

Meister, G., and Tuschl, T. (2004). Mechanisms of gene silencing by doublestranded RNA. Nature 431, 343-349. doi: 10.1038/nature02873

Mello, C. C., and Conte, D. (2004). Revealing the world of RNA interference. Nature 431, 338-342. doi: 10.1038/nature02872

Podolska, K., Sedlak, D., Bartunek, P., and Svoboda, P. (2014). Fluorescencebased high-throughput screening of dicer cleavage activity. J. Biomol. Screen. 19, 417-426. doi: 10.1177/1087057113497400

Price, D. R., and Gatehouse, J. A. (2008). RNAi-mediated crop protection against insects. Trends Biotechnol. 26, 393-400. doi: 10.1016/j.tibtech.2008.04.004

Ren, D., Cai, Z., Song, J., Wu, Z., and Zhou, S. (2014). dsRNA uptake and persistence account for tissue-dependent susceptibility to RNA interference in the migratory locust, Locusta migratoria: tissue-dependent RNAi susceptibility. Insect Mol. Biol. 23, 175-184. doi: 10.1111/imb.12074

Shukla, J. N., Kalsi, M., Sethi, A., Narva, K. E., Fishilevich, E., Singh, S., et al. (2016). Reduced stability and intracellular transport of dsRNA contribute to poor RNAi response in lepidopteran insects. RNA Biol. 13, 656-669. doi: 10.1080/15476286. 2016.1191728

Singh, I. K., Singh, S., Mogilicherla, K., Shukla, J. N., and Palli, S. R. (2017). Comparative analysis of double-stranded RNA degradation and processing in insects. Sci. Rep. 7:17059. doi: 10.1038/s41598-017-17134-2

Sinha, N. K., Trettin, K. D., Aruscavage, P. J., and Bass, B. L. (2015). Drosophila Dicer-2 cleavage is mediated by helicase- and dsRNA termini-dependent states that are modulated by Loquacious-PD. Mol. Cell 58, 406-417. doi: 10.1016/j. molcel.2015.03.012

Song, H., Zhang, J., Li, D., Cooper, A. M. W., Silver, K., Li, T., et al. (2017). A double-stranded RNA degrading enzyme reduces the efficiency of oral RNA interference in migratory locust. Insect Biochem. Mol. Biol. 86, 68-80. doi: 10.1016/j.ibmb.2017.05.008

Spit, J., Philips, A., Wynant, N., Santos, D., Plaetinck, G., and Vanden Broeck, J. (2017). Knockdown of nuclease activity in the gut enhances RNAi efficiency in the Colorado potato beetle, Leptinotarsa decemlineata, but not in the desert locust, Schistocerca gregaria. Insect Biochem. Mol. Biol. 81, 103-116. doi: 10. 1016/j.ibmb.2017.01.004

Swevers, L., Huvenne, H., Menschaert, G., Kontogiannatos, D., Kourti, A., Pauchet, Y., et al. (2013). Colorado potato beetle (Coleoptera) gut transcriptome analysis: expression of RNA interference-related genes: presence of RNAi genes in CPB gut transcriptome. Insect Mol. Biol. 22, 668-684. doi: 10.1111/imb.12054 Terenius, O., Papanicolaou, A., Garbutt, J. S., Eleftherianos, I., Huvenne, H., Kanginakudru, S., et al. (2011). RNA interference in Lepidoptera: an overview 
of successful and unsuccessful studies and implications for experimental design. J. Insect Physiol. 57, 231-245. doi: 10.1016/j.jinsphys.2010.11.006

Tijsterman, M., May, R. C., Simmer, F., Okihara, K. L., and Plasterk, R. H. (2004). Genes required for systemic RNA interference in Caenorhabditis elegans. Curr. Biol. 14, 111-116. doi: 10.1016/j.cub.2003.12.029

Tomoyasu, Y., Miller, S. C., Tomita, S., Schoppmeier, M., Grossmann, D., and Bucher, G. (2008). Exploring systemic RNA interference in insects: a genomewide survey for RNAi genes in Tribolium. Genome Biol. 9:R10. doi: 10.1186/gb2008-9-1-r10

Wang, K., Peng, Y., Pu, J., Fu, W., Wang, J., and Han, Z. (2016). Variation in RNAi efficacy among insect species is attributable to dsRNA degradation in vivo. Insect Biochem. Mol. Biol. 77, 1-9. doi: 10.1016/j.ibmb.2016.07.007

Wyatt, G. R. (1961). The biochemistry of insect hemolymph. Annu. Rev. Entomol. 6, 75-102. doi: 10.1146/annurev.en.06.010161.000451

Wynant, N., Santos, D., Verdonck, R., Spit, J., Van Wielendaele, P., and Vanden Broeck, J. (2014). Identification, functional characterization and phylogenetic analysis of double stranded RNA degrading enzymes present in the gut of the desert locust, Schistocerca gregaria. Insect Biochem. Mol. Biol. 46, 1-8. doi: 10.1016/j.ibmb.2013.12.008

Wynant, N., Verlinden, H., Breugelmans, B., Simonet, G., and Vanden Broeck, J. (2012). Tissue-dependence and sensitivity of the systemic RNA interference response in the desert locust, Schistocerca gregaria. Insect Biochem. Mol. Biol. 42, 911-917. doi: 10.1016/j.ibmb.2012.09.004

Xu, H.-J., Chen, T., Ma, X.-F., Xue, J., Pan, P.-L., Zhang, X.-C., et al. (2013). Genome-wide screening for components of small interfering RNA (siRNA) and
micro-RNA (miRNA) pathways in the brown planthopper, Nilaparvata lugens (Hemiptera: Delphacidae): RNAi pathway in the brown planthopper. Insect Mol. Biol. 22, 635-647. doi: 10.1111/imb.12051

Zhang, H., Li, H.-C., and Miao, X.-X. (2013). Feasibility, limitation and possible solutions of RNAi-based technology for insect pest control: RNAi-based technology in insect pest control. Insect Sci. 20, 15-30. doi: 10.1111/j.1744-7917. 2012.01513.x

Zhang, J., Khan, S. A., Heckel, D. G., and Bock, R. (2017). Next-generation insectresistant plants: RNAi-mediated crop protection. Trends Biotechnol. doi: 10. 1016/j.tibtech.2017.04.009 [Epub ahead of print].

Zhou, G., Kohlhepp, P., Geiser, D., Frasquillo Mdel, C., Vazquez-Moreno, L., and Winzerling, J. J. (2007). Fate of blood meal iron in mosquitoes. J. Insect Physiol. 53, 1169-1178. doi: 10.1016/j.jinsphys.2007.06.009

Conflict of Interest Statement: The authors declare that the research was conducted in the absence of any commercial or financial relationships that could be construed as a potential conflict of interest.

Copyright (c) 2018 Peng, Wang, Fu, Sheng and Han. This is an open-access article distributed under the terms of the Creative Commons Attribution License (CC BY). The use, distribution or reproduction in other forums is permitted, provided the original author(s) and the copyright owner are credited and that the original publication in this journal is cited, in accordance with accepted academic practice. No use, distribution or reproduction is permitted which does not comply with these terms. 